\title{
Older Academics: Motivation to Keep Working
}

\author{
Gillian M Boulton-Lewis ${ }^{1, *}$ \& Laurie Buys ${ }^{2}$ \\ ${ }^{1}$ School of Design and the Office of Education, Queensland University of Technology, Brisbane, Queensland, \\ Australia \\ ${ }^{2}$ School of Design, Faculty of Built Environment, Queensland University of Technology, Brisbane, Queensland, \\ Australia \\ *Corresponding author: Creative Industries Faculty, Queensland University of Technology, Brisbane, Queensland, \\ Australia. E-mail: g.boulton-lewis@qut.edu.au
}

Received: November 6, 2014

Accepted: November 30, $2014 \quad$ Online Published: December 15, 2014

doi:10.5430/wje.v4n6p66

URL: http://dx.doi.org/10.5430/wje.v4n6p66

\begin{abstract}
This is an interpretive - descriptive analysis of responses to 41 open ended questionnaires returned by academics working beyond normal retirement age. The sample consisted mainly of academics from the United Kingdom, Australia, and New Zealand. The research addressed the question of what motivates some academics to continue working beyond the 'usual' retirement age. The main motivation for continuing was strong interest and commitment, particularly to research and writing. Some also gave social, financial, and other reasons for continuing. Those not in full time employment described barriers, including finance and facilities and the support that they needed to maintain their activities. In most countries institutional and government policies made it possible for them to stay involved academically even if it meant making a personal effort. Most of them would have liked better support or recognition from their universities. The results suggest that universities should more actively support older academics in continuing activity.
\end{abstract}

Keywords: academics; ageing; continuing engagement; qualitative; open ended questionnaire

\section{Introduction}

The study was motivated by my interest in continuing to teach and research past the usual retirement age of 65 years in Australia. The research was prompted by attendance at the EARLI (European Association for Research on Learning and Instruction) conference in Exeter in 2011 and my observation that there were quite a few attendees over 65 who seemed to be opting for Manheimer's (2009) fourth option of continuous employment, or at least continuous engagement in academic activities as part of a portfolio for retirement. They could also be classified as identity maintainers (Yeandle, 2005) or choosers (Centre for Research into the Older Workforce (CROW), 2004). The dilemma of some academics was described by a Chinese academic in Hong Kong who said, 'I don't know what I want to do, all my life has been in academic work' (personal communication), although this is unlikely to be the whole explanation. Given that government and institutional policies in some countries discourage people from continuing to be employed it seemed of interest to investigate what motivates some of us to stay engaged in academic activities (sometimes for no financial reward) as we get older. Hence I sent out a call through professional associations and colleagues asking for volunteers from about 65 years and older to respond to a questionnaire regarding what motivates their continuing interest in academic activities.

\section{Literature Review}

\subsection{Active Ageing}

There is not a great deal of research that takes account of what older people themselves think is important for them in active ageing. Boulton-Lewis and others (2010; 2012) found that generally older adults are motivated to learn about technology, leisure activities, and new things. "Young-old" adults were more likely to want to learn than "old-old" adults, and their reasons were to keep their minds active and stay mentally stimulated. Some older adults believed 
that their most important learning needs were associated with transportation, health and safety; that they could address these but had difficulty learning the use of new technologies. Generally older adults are motivated to learn about technology, leisure activities, and new things. "Young-old" adults were more likely to want to learn than "old-old" adults, and their reasons were to keep their minds active and stay mentally stimulated. These results were for a sample obtained through National Seniors in Australia. That study did not directly address the issue of whether participants wanted to continue working although some were still in employment.

Variability between individuals in terms of learning increases as people get older (Rabbit (Charness, 1992; Rabbitt, Diggle, Holland, \& McInnes, 2004), and the critical issue, in terms of age and performance is how the older person compensates for changes in processing speed and working memory. Obviously the nature and amount of learning achieved in early and middle life impacts on the capacity of older adults when they are learning new skills and knowledge in later life in areas where they already have expertise. Older academics who are not suffering from any cognitive impairments should have years of acquired knowledge and skills that allow them to continue learning and performing at a high level in their areas of expertise.

\subsection{Working and Ageing}

Clayton (2010) reviewed European data for working and ageing and identified that the two most important reasons for working after usual retirement age (normally 65) were financial necessity and job satisfaction. The main financial reasons for continuing to work were to build up savings or a pension, either through necessity or choice. Many people who work as they get older demand more control in their lives (McNair, 2006) and this might explain why those with better qualifications work longer as they are likely to have more autonomy and incentive to continue. Enabling factors for continuing to work were qualifications (higher level, computer expertise), job availability, attitudes and policies of employers, personal health, government policies and vocational guidance and mentoring. Simova (2010) in a Czech study found reasons for continuing work included finance, satisfaction at work, health, expected satisfaction in retirement, and employer preferences. Finance was linked to the need to earn money to maintain standard of living. Simova also identified the key role of education as an underlying supporting factor. People who had engaged in self directed learning and who could prove their expertise formally were more likely to remain employed. Positive responses to keep working were more common from people who could use the Internet, spoke more than one language, who were experts, or who were in executive positions. Some also said that they did not want to lose contact with people at work or wanted to be useful. Clayton (2010) proposed that working after usual retirement age is and should be should be a matter of individual choice. However, only a small proportion of those aged 65-69 years in Europe stay in employment (Eurostat, 2008). In the US 19\% in their 70s are still working (Oxford Institute of Ageing, 2007).

Various models have been proposed for post retirement activities. They depend in part on job satisfaction, work/life balance, and attractiveness of various options. Older people have mixed motives for continuing to work as described above. It is suggested that older people who continue to work want flexibility, including higher levels of part time work for a variety of reasons; to spend time with family and friends, for hobbies, caring responsibilities, health problems, to avoid boredom, and to meet people.

Manheimer (2009) proposed four post-career models in the context of North America: neo Golden (pursuing self development and social adaptation), second career orientation (dream job), portfolio life (balance of family, leisure, work and travel), and continuous employment (extension of midlife career). The associated learning needs for these are as follows: neo Golden (enrichment, socialization, new skills), second career (learning new skills and new businesses), portfolios (to meet interests, needs and new career skills) and continuous employment (new skills to keep up for employment purposes). These four models highlight the fact that people as they age want a range of different lifestyles and therefore have differing learning needs and expectations. Other post career models propose similar categories. Yeandle's (2005) classification of motivation to continue working is as follows: Career changers want to try something new; Downshifters - want less stress, and more autonomy; Identity maintainers - use existing skills in another setting; and Workers until they drop - usually have to work until forced to stop. Centre for Research into the Older Workforce (CROW) (2004) divides continuing workers into; Choosers - usually highly qualified who will continue if interested; Survivors - with low qualifications who stay until forced out; and Jugglers - usually women with medium level qualifications who are least likely to stay on working.

\subsection{Academic Productivity and Ageing}

The question of the relation between age and productivity seems to have no conclusive answer.

The research into the relation between age and impact or productivity falls into two categories (Gingras, Larivière, 
Macaluso, \& Robitaille, 2008). The first category, which focuses on extraordinary achievements such as winning the Nobel prize, shows that these usually occur before the age of 40 and that generally younger researchers are more productive than older ones. Another body of literature found that researchers in the middle of their careers and beyond have greater scientific impact. As explanation for the first category it is suggested that individuals have a creative potential that decreases over time. For the second category an explanation is that as researchers grow older and gain more experience and expertise they have access to better resources and this increases their productivity and impact.

Lifetime research productivity was examined for a sample of eminent Australian academics when they were aged 79 -90 years (Christensen \& Jacomb, 1992). Overall their publications peaked at 50 years and then declined. However there were different age peaks for different types of publications: 40-49 for journal articles, 50-59 for new books and cross disciplinary publications, and 60-69 for edited, technical and non technical books. It is suggested that these peaks could be an effect of ageing or of cohort effects in research and publication. It makes sense however that as academics age and gain experience they are likely to mentor others or collaborate in groups.

The question of productivity is only important if academics continue in full time positions, are not contributing fully to the university research profile and preventing younger academics from being promoted. On the other hand older academics can have much to offer their colleagues. Flaherty (2013) described how 195 professors, who responded to a survey in the United States are putting off retirement and not just for financial reasons. For example 81\% wanted to continue for professional and personal reasons: to stay busy and productive, love the work, want continued affiliation with institution. Only $69 \%$ were motivated by economic concerns. In the large number of online comments on this article some were concerned by the problem this would cause for younger academics and phased retirement was suggested. One way of doing this is to allow academics to continue in an emeritus role with some support.

Ageism, defined as the assumption that someone's age makes him or her less able to work (Clayton, 2010, 239) can bring about discrimination based on fixed retirement age and stereotyping. It can be argued that retaining older workers promotes workforce diversity. On the other hand it could be argued that older staff members are an impediment to recruitment of new staff if institutions have a fixed or diminishing budget for salaries. The advantages and disadvantages of keeping or losing expertise need to be considered carefully. Where there is a skill shortage and declining pool of younger workers' employers are more likely to value the skills and experience of older workers and hence this will affect some policies and attitudes. Government policy and pensions also affect decisions to continue working.

\subsection{Emeritus Professors}

Thody (2011) researched the professional and leisure activities in retirement of emeritus professors of an English university (fictionally named Borchester). She focused on how much they used university facilities and how much use universities made of their knowledge. Because ageism is now partly prohibited in the UK she suggested that it may make it easier for academics to remain in full-time employment beyond 65 if they wish. She found that about half of them were happy to be active in teaching and research though not all were recognized or remunerated by their universities. She also found that there were few emeritus centres or associations that they could join.

Specifically in describing their activities she found that only one quarter (of about 40) registered disinterest in continuing in research or professional activities. Writing of various kinds was the most significant professional activity although not all were recorded in the university's research output. Some published more than they had before retirement and enjoyed research, some of it self - funded. There were fewer teaching activities. Some saw retirement as freedom to choose their own work. They also described involvement in leisure and home activities, and professional and academic societies. About half were entitled to library and Internet use but did not necessarily ask for them and about a quarter had use of a personal/shared office. About half were satisfied with their treatment although their opinions here varied. Suggestions for improvement included regular part time and research employment, websites, mentoring and committee work. None favoured a national emeriti body although a range of such provisions exist in the US. She concluded that 'The next stage is to see whether universities and retired professors can better facilitate emeriti action and goodwill to assist the universities, alter perceptions of ageing, support their retired staff... and work out how to cope with staff who will no longer have a mandatory retirement date.' (Thody, 2011, 652). 


\section{Method}

This research was intended to find out what a sample of academics who have continued to work, full time or part time, paid or unpaid have to say about their reasons for doing so.

The study was qualitative relying on open ended responses to a list of issues contained in a questionnaire. The sample was purposive and self-selected. A call was sent out through professional associations and networks of colleagues to academics aged 65 years and over, who were still engaging in academic activities either employed or voluntary, to be involved in the research. A few people a year or so younger than 65 heard of the research and also wanted to be involved. The analysis was interpretive -descriptive as described below.

\subsection{Participants}

The participants consisted of 21 women and 20 men, and the mean age was 69 years. The youngest and oldest were 61 and 85 respectively. There were 16 from the United Kingdom including 2 from Scotland, 11 Australians, 4 New Zealanders, 3 from USA, 3 from Italy, 3 from Hong Kong, 1 from Switzerland and 1 from Canada. A wide range of disciplines and academic areas was represented. Twenty-seven were professors (some emeritus or adjunct) and the others were associate professors, senior academics, consultants and researchers. Thirteen were still working full time and the rest were choosing to continue their work voluntarily or part time. Table 1 is a summary of the sample and the number given to each respondent is attached to the illustrative quotes. It can be seen that the sample is mostly drawn from the Western world and hence cannot claim to represent the older academic population internationally.

Table 1. Participant Details

\begin{tabular}{|c|c|c|c|c|c|}
\hline Part. & $\begin{array}{l}\text { Gender/ } \\
\text { Age }\end{array}$ & $\begin{array}{l}\text { FT/PT/PT,V } \\
\text { (Voluntary) }\end{array}$ & Expertise & $\begin{array}{l}\text { Main motivation } \\
\text { for involvement }\end{array}$ & Country \\
\hline 1 & $\mathrm{~F} / 74$ & Prof Em/V & Ed Psych & Interest and contact & Italy \\
\hline 2 & $\mathrm{M} / 65$ & Prof Em/V & Teacher Ed & $\begin{array}{l}\text { Strongly interested in educational/social } \\
\text { research, statistical methods }\end{array}$ & Switzerland \\
\hline 3 & $\mathrm{M} / 74$ & Prof Em/V & Teaching/Learning & $\begin{array}{l}\text { Interest in research/ } \\
\text { contact with colleagues }\end{array}$ & Scotland \\
\hline 4 & $\mathrm{~F} / 74$ & Dist Prof/FT & $\begin{array}{l}\text { Mathematics } \\
\text { Education }\end{array}$ & $\begin{array}{l}\text { Earning, learning and } \\
\text { creativity }\end{array}$ & USA \\
\hline 5 & $\mathrm{M} / 65$ & Prof/FT & Adult Education & Enjoy work, contribute, salary a bonus & Hong Kong \\
\hline 6 & $\mathrm{M} / 70$ & Prof Em/V & Archaeology & $\begin{array}{l}\text { Passion, commitment, } \\
\text { collaboration }\end{array}$ & England \\
\hline 7 & $\mathrm{~F} / 62$ & Director/FT & Student Learning & $\begin{array}{l}\text { Love the work, make a } \\
\text { difference, research, finances }\end{array}$ & $\mathrm{NZ}$ \\
\hline 8 & $\mathrm{~F} / 65$ & A/Prof/FT & Health Sociology & $\begin{array}{l}\text { Interested in all aspects of } \\
\text { work, will volunteer }\end{array}$ & Australia \\
\hline 9 & $\mathrm{~F} / 65+$ & $\mathrm{Dr} / \mathrm{FT}$ & Surgery & Interest & Australia \\
\hline 10 & $\mathrm{~F} / 67$ & A/Prof/FT & Teacher Ed/Research & Intellectual challenge, working with others & $\mathrm{NZ}$ \\
\hline 11 & $\mathrm{M} / 68$ & S Lecturer/FT & Info Man Systems & Finances, also enjoys work & NZ \\
\hline 12 & $\mathrm{M} / 71$ & Prof/FT & $\begin{array}{l}\text { Education/Research } \\
\text { Methodology }\end{array}$ & Research, not sure what else would do with time & Australia \\
\hline 13 & $\mathrm{M} / 82$ & Dr/Adj/V & Aboriginal Ed & $\begin{array}{l}\text { Make up for late involvement, unique experience } \\
\text { and knowledge }\end{array}$ & Australia \\
\hline 14 & $\mathrm{~F} / 67$ & Adj RA/PT & Language and learning & $\begin{array}{l}\text { Contribution, need for expertise, mental } \\
\text { stimulation }\end{array}$ & Australia \\
\hline 15 & $\mathrm{~F} / 70$ & Ass Dean/PT & Arts/Academic Dev & Things to contribute, salary allows travel & NZ \\
\hline 16 & $\mathrm{~F} / 71$ & Prof Em/Adj/FT & Ed Psych & $\begin{array}{l}\text { Research, make use of knowledge, } \\
\text { salary allows travel, stay cognitively engaged }\end{array}$ & Australia \\
\hline 17 & $\mathrm{~F} / 63$ & Prof/Em/Adj/ V & Teaching/Learning & $\begin{array}{l}\text { Finish ongoing work, share wisdom, sustain } \\
\text { sanity in difficult situation }\end{array}$ & Australia \\
\hline 18 & $\mathrm{M} / 69$ & Prof/V & Greek History & Finish what started & England \\
\hline 19 & $\mathrm{~F} / 70$ & Em Prof/V & History/Women & $\begin{array}{l}\text { Attachment to field, finish projects, mental } \\
\text { stimulation }\end{array}$ & Australia \\
\hline
\end{tabular}




\begin{tabular}{|c|c|c|c|c|c|}
\hline 20 & $\mathrm{~F} / 65$ & Res Fellow/FT & Genetics & Enjoy work, research, don't feel old enough & Australia \\
\hline 21 & M/65 & Prof/V & Jewish Studies & $\begin{array}{l}\text { Continued love of subject, pursuing interests, } \\
\text { communicate, complete research }\end{array}$ & England \\
\hline 22 & M/65+ & Prof/V & Philosophy & $\begin{array}{l}\text { Still things to say about subject, reading, writing } \\
\text { research }\end{array}$ & England \\
\hline 23 & M/66 & Reader/V & Ottoman History & $\begin{array}{l}\text { Continued interest in research, contractual } \\
\text { obligations, requests for expertise }\end{array}$ & England \\
\hline 24 & M/64 & Professor/V & Linguistics & $\begin{array}{l}\text { Research is my `hobby', choice of spare time } \\
\text { activity }\end{array}$ & England \\
\hline 25 & $\mathrm{~F} / 61$ & Prof Em/V & Political Philosophy & $\begin{array}{l}\text { Contact, contributing to pbns. Helping old } \\
\text { colleagues, but would like to make a break }\end{array}$ & England, \\
\hline 26 & $\mathrm{M} / 72$ & Prof Em/V & $\begin{array}{l}\text { Psychometrics } \\
\text { History of psychology }\end{array}$ & $\begin{array}{l}\text { It is the lone thing I can do and it satisfies me. } \\
\text { Till now, we old academics (especially emeritus) } \\
\text { have no problems of support, but Italian politics } \\
\text { is a real mess, and we are all worried about the } \\
\text { future }\end{array}$ & Italy \\
\hline 27 & $\mathrm{~F} / 63$ & Consultant/PT & HEd, Ex PVC & $\begin{array}{l}\text { Income and personal fulfilment. } \\
\text { Giving back and mentoring. }\end{array}$ & England \\
\hline 28 & $\mathrm{~F} / 71$ & Prof Em/V & $\begin{array}{l}\text { Dev Psych, cognitive } \\
\text { and emotional }\end{array}$ & Work is rewarding, active writer and researcher & Italy \\
\hline 29 & M/67 & Affiliate/ PT & $\begin{array}{l}\text { Political Science } \\
\text { Financial markets }\end{array}$ & Intellectual interest & England \\
\hline 30 & M/65 & Prof// FT & Ed Psych & $\begin{array}{l}\text { Remain active intellectually, Institutional } \\
\text { willingness to continue my employment, further } \\
\text { contribution to profession, development of } \\
\text { younger academics }\end{array}$ & Hong Kong \\
\hline 31 & $\mathrm{M} / 75$ & Prof/PT/V & $\begin{array}{l}\text { Education } \\
\text { Classroom observation }\end{array}$ & Pleasure, utility, consultancy, mentoring & England \\
\hline 32 & $\mathrm{~F} / 65^{+}$ & Prof Adj/PT & Education & $\begin{array}{l}\text { Enjoys work, not ready to retire, teaching and } \\
\text { researching }\end{array}$ & Canada \\
\hline 33 & $\mathrm{~F} / 65$ & Em Prof/V & $\begin{array}{l}\text { Dev disabilities } \\
\text { Child psychology }\end{array}$ & Lifetime interest & Scotland \\
\hline 34 & $\mathrm{~F} / 67 /$ & Professor FT & $\begin{array}{l}\text { Primary Health Care } \\
\text { Nursing research }\end{array}$ & Loves the work and stimulation & USA \\
\hline 35 & $\mathrm{~F} / 68$ & $\begin{array}{l}\text { Research Fellow } \\
\text { Honorary/ V }\end{array}$ & Archaeology & $\begin{array}{l}\text { Unfinished projects and new data relating to } \\
\text { previous projects...more reflective approach } \\
\text { (possibly because free of shackles of other } \\
\text { duties) }\end{array}$ & England \\
\hline 36 & $\mathrm{~F} / 82$ & Em Prof/ PT & Child protection & My expertise is in great demand & Australia \\
\hline 37 & $\mathrm{M} / 73$ & $\begin{array}{l}\text { Honorary } \\
\text { University Senior } \\
\text { Research } \\
\text { Fellowship /FT }\end{array}$ & $\begin{array}{l}\text { Human anatomy, } \\
\text { osteoarchaeology; } \\
\text { forensic anthropology }\end{array}$ & $\begin{array}{l}\text { Interest. For some years I spent every vacation } \\
\text { examining human skeletal remains for } \\
\text { archaeologists in Greece }\end{array}$ & England \\
\hline 38 & M/85 & $\mathrm{V}$ & $\begin{array}{l}\text { Anatomy, Pathology, } \\
\text { Vet Medicine }\end{array}$ & $\begin{array}{l}\text { Interest in science and wishing to remain } \\
\text { mentally and physically active }\end{array}$ & England \\
\hline 39 & $\mathrm{~F} / 74$ & $\mathrm{~V}$ & $\begin{array}{l}\text { Biochemistry } \\
\text { Medicine }\end{array}$ & $\begin{array}{l}\text { To keep my brain active and to "repay" society } \\
\text { the debt I incurred during my long and happy } \\
\text { scientific "life" }\end{array}$ & USA \\
\hline 40 & $\mathrm{M} / 75$ & $\begin{array}{l}\text { V/Independent } \\
\text { writer }\end{array}$ & $\begin{array}{l}\text { Applied philosophy of } \\
\text { Education }\end{array}$ & $\begin{array}{l}\text { I believe in autonomous lifelong learning as } \\
\text { intrinsic motivation. Retirement has provided } \\
\text { opportunities to adapt my continuing research } \\
\text { and writing }\end{array}$ & Australia \\
\hline 41 & $\mathrm{~F} / 78$ & Em Prof /V & Child welfare/education & $\begin{array}{l}\text { Obligation to publish findings... frequent } \\
\text { invitations to speak and publish ... keep going as } \\
\text { long as I can to get the message over. }\end{array}$ & England \\
\hline
\end{tabular}

It has been asserted by Sandberg (2000), for phenomenographic interviews, that after 20 or so interviews the number of conceptions reaches saturation. Likewise Douglas (1985) 'estimated that in-depth interviews with twenty-five 
people were necessary before he reached the saturation point' (cited in Maykut \& Morehouse, 1994, 63). Lincoln and Guba (1985) suggested that a carefully selected sample of 12 would be sufficient to identify the range of issues. Hence a sample of 41 responding to an open questionnaire should be more than sufficient to reveal the range of issues concerning continuing academic work in the sample population as people age.

\subsection{Questionnaire}

Because this study was conducted without funding it was not possible to carry out interviews internationally. Hence an open ended questionnaire was designed as a substitute (included as Appendix 1). The draft questionnaire was sent to early responders and they were asked if they wanted to comment on it, improve it, or add to it. Three of the participants did that. Participants were asked to provide demographic information and respond in an open ended way to questions about the following issues; their main reasons for continuing involvement in academic work, their current activities, their areas of expertise, their ideal range of academic and other activities, what aspects of their work they needed to keep up with, barriers, support needed, changes needed in institutional or government policies, and anything else they wanted to add. An ongoing dialogue occurred with about a third of the participants when they or the researcher wanted to clarify issues.

\subsection{Analysis}

The research is interpretive - descriptive (Maykut \& Morehouse, 1994). It is exploratory and reliant on people's words and meanings (Belenky cited in Maykut \& Morehouse, 1994). The method is based mainly on the work of Lincoln and Guba (1985). In interpretive - descriptive research the approach to data collection and analysis is inductive. Data collected are related to the focus of the issues to be investigated and the propositions emerge from a constant comparative method of data analysis (Strauss \& Corbin, 1997).

The responses were analysed to determine the factors and issues that contribute to continuation of academic work. The aim was to accurately describe and interpret the reality for the people who participated in the study. The author read and reread the responses to derive categories and select appropriate quotes to illustrate these. Then in a further iteration these were compared with literature in the area. The draft paper was presented at a small conference and sent individually to all the early participants who were asked to add further comments or correct and elucidate some of the interpretations. In that sense it is a collaborative work by a group of older academics who were interested in making their views known on why they believed they should stay involved in academic activities.

\section{Results}

The data are described according to five main categories: motivation, current activities, facilitators and barriers to continuing to work, ongoing needs, and institutional and government policies.

\subsection{Motivation}

The motivation for continuing academic activities were varied. However the main motivation described by participants for continuing to be involved in academic activities was strong interest and commitment to what they were doing. Some participants also stated that they wanted to keep sharing/using their knowledge and skills. A few said that their colleagues and their work constituted their main social activity and five said that financial reasons were a consideration. Other reasons included mental stimulation and staying actively engaged in their research areas.

\subsection{Interest}

The majority of the participants were continuing to work because they were interested in or enjoyed what they were doing. This interest ranged in degree from a passion, to filling the place of a hobby, a buzz, to continuing interest in researching and writing, to not knowing what else to do with their time because this was what they had done all their working life. In most cases their academic interests had been life long and there was no reason for the interest to cease as they aged.

'A continuing passion for my subject .... a belief that I still have a lot to give.' (6)(Note 1)

'Continued love of my subject. The academic life has been for me something of a vocation. I have been driven by a desire to understand my subject... it has never been dictated by the need to earn a living....and the fact that I have... has been a bonus' (20)

'My academic research interests fill the place of a hobby, that is to say the thing I most like spending my free time on (when not eating, drinking or being with my family!)' (23)

'I've been in academia my whole working life...Academic life never stops; only the salary does. It is difficult 
to explain to people outside of academia why we continue to work post-retirement but as so many of us do, there presumably must be a good deal of personal satisfaction in it (32)

\subsection{Sharing/Using Knowledge/Ongoing Commitments}

A large number of the participants said that they had contractual or collaborative commitments, were involved in ongoing projects, needed to finish their writing or research, had knowledge that they wanted to keep using or sharing, or wanted to give back and mentor younger colleagues.

'Continuing contractual obligations...request for reviews, conference contributions...' (22)

' want to finish what I started [book]... continuing research.' (17)

'ongoing work to complete ... share skills ....remain engaged with academics worldwide.' (16)

'I still have things to say about the subject I'm interested in.' (21)

'I have a contribution to make...expertise that I can supply.' (13)

'I have always judged the contact with new citizens a very important advantage of my work.' (1).

'I believe I can make a difference in the lives of our students.' (7)

\subsection{Social Benefits}

Participants valued personal social contacts with their universities, networks, collaborators, and their research community. One said that after retirement it would be necessary to find new friends. A few also lamented that once they retired they really had no place to meet and talk as they used to do.

'Desire to keep in touch with colleagues ... in several countries with whom I have been collaborating recently.'

(3)

'Colleagues become important in one's life' (15)

\subsection{Finances}

Six participants gave financial reasons, in part, for their decision to keep working. For some participants the continuing salary was necessary, for others it was a bonus that allowed for travel and other expenses.

'My university career started at 48...I had to earn enough so that my retirement accounts will support me when I choose to retire.' (4)

'The third reason is very practical; I can’t afford to retire.' (7)

'I have to keep working until I am entitled to receive ... payments... it is not a burden as I enjoy my work.' (10)

'The extra income, above my university superannuation has paid for extended overseas travel, photographic activities...changes to the house and garden.' (14)

\subsection{Mental and Cognitive Wellbeing}

There was some mention of the ongoing benefits of mental stimulation, staying cognitively active, maintaining sanity in an otherwise difficult situation, or staying engaged to compensate for loss of a partner.

'research from the cognitive and neurosciences ... may throw light on continuing learning needs and potentials of older academics, that may alter conventional knowledge on how older academics are perceived in our society' (40)

'working keeps my brain active. Having a husband with accidental-injury related dementia I am very aware of the need for that' (36)

\subsection{Current Activities}

Those in full time employment were mostly maintaining the full range of academic activities. Of those who were working voluntarily or part time, activities included some teaching and lecturing (7(Note 2)), administration (2), consultancy and advising (2), supervision and mentoring (5), involvement with learned societies and conferences (8). However the main activity of choice in part time retirement seems to be research, writing, publishing and presentations (23). Of course most of these activities are usually combined. One respondent completed a $\mathrm{PhD}$ in retirement. The respondent below summed up his ideal retirement as follows.

'I have the ideal. I have no teaching or administrative duties and the international research work I undertake, enables me to visit friends and academic colleagues in the USA and Southern Hemisphere. I enjoy what I do and think myself fortunate to be able to do as much or as little as I please' (31) 
Another said that when she retires she does not want any administration.

'I want only to do research and teach... I have had more than enough "deaning” ،

(34).

\subsection{Facilitators/ Barriers}

Those in full time employment mostly described good support for their activities: however there was some suggestion of ageism in their institutions and their need to make an effort to continue to be employed. Those working part time, or voluntarily, described a range of factors that made their ongoing work easy or difficult. Facilitators included good support from their institutions and good health.

\subsection{Facilitators}

‘...reappointment for another 5 years to work until I am 80.’ (4)

'...my ability to continue this at the age of 82 has been aided by good health...' (12)

'In the end I retained my university email, use of a room in my old department, access to car parking, and access to the university library.’ (20)

'One reason I keep working is to have access to all the support of the university' (34)

\subsection{Barriers}

Barriers, although not insurmountable, included aspects of funding and provision of appropriate facilities, some age related obstacles such as being overlooked or taken for granted, and poor institutional support or recognition. Three participants also suggested that unless the older academic stayed up to date and energetic they should not keep working thus raising the question of productivity.

\subsection{Funding and Facilities}

'Financial support ....is rather difficult to obtain by my `regular’ colleagues as well...' (1)

' ...getting even minor funding and support for raising grants becomes much more difficult once one is outside the neat bureaucratic box.' (6)

'....as an adjunct I need to apply for research grants with a full time colleague.' (15)

'the one thing I no longer have is access to travel funds ...there would seem to be no reason, other than perhaps shortage of funds, why an institution should not accept applications for conference support from retired staff ...'(23)

'I fund my academic activities out of book royalties but have to pay for everything out of my own resources' (41).

'financial pressures at work in higher education in the USA... our university just offered folks with long service $1 / 2$ their annual salary to retire. We lost 15 highly productive, experienced, wise colleagues as a result. The pressure is on to remove the long-serving, higher paid, academics in universities here' (34)

\subsection{Age related Obstacles and Personal Comments}

Some participants were aware of age related obstacles to their work but believed that they could still continue effectively, albeit acknowledging that they had to make a greater effort. Obstacles included energy levels, hearing, motivation, physical ability, all of which they had to overcome.

‘...decreasing levels of energy...' (3)

'My hearing is poor even with aids...classrooms are designed... to lose the [sound] waves in high ceilings ...' (4)

'....it is harder to motivate oneself to write when there are no external deadlines.' (15)

'I am conscious that my age is a hindrance when I stand in front of a large class of first year

students.'(10)

'General problems of ageing including reduced ability to carry out prolonged physical (and mental) work. Greater effort needed to learn new techniques and to remember new details’ (38)

4.13 Personal

A few believed that they owed it to their family or partners to slow down their engagement.

'... [need for] spending rewarding time with my family...' (9)

‘...you cannot spend 70 hours a week if your partner would like some time with you.' (8) 
'Care - giving commitments.' (16)

\subsection{Irrelevance or Being Overlooked}

It was noted that once you are retired, even if you are still active in a part time or voluntary capacity you are often overlooked or seen as irrelevant.

'the longer you are retired the less people think you are still active' (3)

'once you retire the water rushes over your space as if you did not exist...'(8)

'...the administration does not take advantage of the kinds of expertise and experiences I have...' (4)

'Most of my continuing involvement has been at the behest of academic women who are still working and at my own initiative; I sense a gender issue here...' (16)

\subsection{Productivity}

The question of productivity was raised by a few participants and their views, both positive and negative, were as one would expect from other research. The question was also alluded to indirectly in terms of greater effort required under age related obstacles above.

\subsection{Positive Comments and Negative Comments}

'I also have a bit more time to dedicate to the research of which I enjoy thoroughly' (28)

'I know of academics who should have retired at 45 or earlier! Age is not a determinant of the level of contribution that academics make (35)

'I have worked in places where there is no retiring age and found it unsatisfactory because people who were clearly incompetent were able to retain paid positions. I think a fixed retirement age is probably reasonable if those who have retired and are still physically and mentally active are permitted to seek re-engagement for relatively short fixed terms at a lower salary and do not block promotion of intelligent junior colleagues' (38)

'a critical phase in an academic's career comes in their fifties. This can be a time when they may lose heart, and their interest in their subject begins to flag. They can become deeply cynical of constant management initiatives. I have seen a small but significant number of bitter and disillusioned academics in their fifties' (21)

\subsection{Ongoing Needs}

Those participants working voluntarily or part time said they needed to maintain, if possible, some office space, access to the Internet and libraries, networks and colleagues, keep up with developments in their field, and have opportunities to communicate through lectures, presentations or conferences.

'having access to an office would be a help.'(13)

'...some... teaching in order to communicate with new generations...' (1)

'[learning to use] newer versions of IT...' (8)

\subsection{Personal Effort}

' ...we have to make ourselves appreciated as persons and researchers in order to be considered as a useful, precious component of our academic community. '(1)

'continuance does require a lot of motivation and effort to keep up with, and to a certain extent, exceed the productivity of younger members of staff (30).

\subsection{Institutional and Government Policies}

Most of the participants, with exceptions in two countries, said that there was now no mandatory retirement age in their universities. However decisions about whether to continue an older academic's employment depend on a range of factors including local need, finances, and their unique expertise and university funding. In the US 'the age discrimination act prevents universities from forcing retirement' and as 'the British government has been encouraging firms to keep on older workers', that could influence universities to do the same. Some of the participants would have liked better support or recognition from their universities and described the personal effort they had needed to make to stay employed. It was also suggested that they could be mobilised better in a variety of ways to promote and support the university.

\subsection{Better Support and Recognition from the University}

'No facilities made available by the institution for which one has slaved for over 30 years, with the institution 
nevertheless getting kudos for one's continuing publication.' (21)

'...I had to work harder than I thought to get the present satisfactory situation. My university showed little interest in helping me to retire.' (20)

'In my case my institute and I agreed to low part time employment which ensures...access and gives me all the freedom and flexibility ...you can concentrate on your favourites [rather than] stop completely or continue fully until you are exhausted.'(2)

'Perhaps better support structures that acknowledge the key role that older academics can play in society would be desirable.'(7)

'....astonished at the lack of interest my university has in mobilizing retired academics to support it...many of these will be retiring at the height of their reputation and could be used in all sorts of ways to promote their university and to continue to add value...' (20)

'I think mandatory retirement should be abolished and merit based continuing employment be the norm (30)

'I feel the University still appreciates the presence and contribution of the small number of senior members who remain academically active. We belong to our Institute for Advanced Studies which gives us some representation'

'Would like to see provision for older academics to be called on as research assistants for relevant university projects' (40)

\section{Discussion and Conclusion}

In summary most participants gave their main reason for continuing engagement in academic activities as interest and commitment to researching and writing. Some also wanted to share their expert knowledge, stay cognitively active, or keep earning an income. The majority were focussing on research and writing. Those in full time employment had good support whilst those continuing voluntarily described some barriers. Almost all participants said that ideally they needed office space, access to Internet and libraries, contact with networks and colleagues and opportunities to communicate with the academic community. In all but two countries institutional and government policies made it possible for them to keep working even if they had to make a personal effort for this to happen. Almost all of them would have liked better support or recognition from their universities.

These results are not surprising. If you have been passionately interested in an aspect of knowledge and research there is little reason why you would cease to be interested as you become older. In fact as one person (personal communication) suggested to me you might be too involved to even think about ageing until you were obliged to slow down or stop. The overall activity profile of these academics from their open ended statements is similar to that described by Thody (2011), that is, with a main focus on research and writing, and supplements the results that she obtained from a less open ended research process in one university. It is also consistent with the results obtained by survey in the USA by Flaherty (2013) where 81\% wanted to continue for personal or professional reasons.

The participants were researchers, learners and teachers by occupation. This group of older academics, for the most part, wanted to keep learning and stay engaged with their chosen areas of expertise. A few did mention travel or new leisure activities but most seemed interested in continuing their life's work. They were obviously in good cognitive and general health and able to function at a high level in their areas of expertise despite perhaps needing occasionally to make a greater effort. They were choosing, as suggested earlier, the fourth option of continuous employment, or at least continuous engagement in academic activities as part of a portfolio for retirement. They could also be classified as identity maintainers and choosers.

Their choices are consistent with the research in ageing and working (Clayton, 2010; Šímová, 2010). Their main reason for continuing to work was interest. To a lesser extent some were also involved for financial reasons although for others it involved some personal financial input and effort. They were able to maintain control over their activities and interests to a great extent. They possess enabling attributes such as higher level qualifications, and/or computer expertise and most of them were fortunate with job availability or ongoing usefulness and respect from their institutions or research communities. These people made an individual choice to stay involved and keep working, sometimes through some considerable personal effort.

The participants made suggestions about how their universities could involve them more effectively and make use of their skills and expertise. Government policies facilitate continuing involvement except in two countries. However 
the decisions on continuing employment depended on situational and personal factors. The continuing activities of this group of older academics and others like them could be influential in helping others to stay actively involved as they age both in universities and in other work areas. There is a need for examples such as this to combat ageism and discrimination. A good case can be made for retaining experts in the workforce to work with younger workers generally and in particular in universities where some of their expert knowledge is unique. This is especially the case where many of these academics are continuing to be involved for their love of the work.

Universities could assist with better structures to provide some support to older academics who, for the most part, want to continue to research and write because of their interest in their discipline. They could phase retirement. They could provide basic office, library, and Internet support. In return for acknowledging publications and other scholarly activities as part of their overall output, perhaps conference attendance and small research grants could be considered. Most of the people who responded were not expecting to be paid, just to be assisted minimally to continue what they want to do.

This paper is a focus on older academics. It would be interesting to conduct further research with other professional groups.

\section{References}

Boulton-Lewis, G. (2010). Education and Learning for the Elderly: Why, How, What. Educational Gerontology, 36(3), 213-228. http://dx.doi.org/10.1080/03601270903182877

Boulton-Lewis, G., \& Tam, M. (2012). Active Ageing, Active Learning: Issues and Challenges (Vol. 15). Dordrecht: Springer Netherlands.

Centre for Research into the Older Workforce (CROW). (2004). Are Older Workers Different? Briefing Paper No. 1. Guilford: Centre for Research into the Older Workforce, University of Surrey.

Charness, N. (1992). Age and expertise: Responding to Talland's challenge. In L. W. Poon, D. C. Rubin \& B. A. Wilson (Eds.), Everyday Cognition in Adulthood and Late Life. Cambridge: Cambridge University Press.

Christensen, H., \& Jacomb, P. A. (1992). The lifetime productivity of eminent Australian academics. International journal of geriatric psychiatry, 7(9), 681-686. http://dx.doi.org/10.1002/gps.930070910

Clayton, P. M. (2010). Working on: choice or necessity? In European Centre for the Development of Vocational Training (Cedefop) (Ed.), Working and ageing: Emerging theories and empirical perspectives. Luxembourg: Publications Office of the European Union.

Eurostat. (2008). The life of women and men in Europe: A statistical portrait. Data 1980-2000. Luxembourg: Office for Official Publications of the European Communities.

Flaherty, C. (2013). Working Way Past 65. Retrieved 25 June, 2013, from https://www.insidehighered.com/news/2013/06/17/data-suggest-baby-boomer-faculty-are-putting-retirement

Gingras Y, Lariviere V, Macaluso B, \& Robitaille J-P. (2008). The Effects of Aging on Researchers' Publication and Citation Patterns. PLoS ONE, 3(12), 40-48. http://dx.doi.org/10.1371/journal.pone.0004048.

Lincoln, Y. S., \& Guba, E. G. (1985). Naturalistic inquiry. Beverly Hills, Calif: Sage Publications.

Manheimer, R. J. (2009). New paradigms for old: Trends and developments in later life learning in North America. Retrieved July 24, 2009, from http://www.lancaster.ac.uk/depts/conted/AEAconference.htm

Maykut, P. S., \& Morehouse, R. (1994). Beginning qualitative research: a philosophic and practical guide. Washington, D.C; London: Falmer Press.

McNair, S. (2006). How Different is the Older Labour Market? Attitudes to Work and Retirement among Older People in Britain. Social Policy and Society, 5(4), 485-494. http://dx.doi.org/10.1371/journal.pone.0004048.10.1017/S1474746406003198

Oxford Institute of Ageing. (2007). The future of retirement: The new old age. London: HSBC Insurance.

Rabbitt, P., Diggle, P., Holland, F., \& McInnes, L. (2004). Practice and drop-out effects during a 17-year longitudinal study of cognitive aging. The journals of gerontology.Series B, Psychological sciences and social sciences, 59(2), 84-97. http://dx.doi.org/10.1093/geronb/59.2.P84

Sandberg, J. (2000). Understanding Human Competence at Work: An Interpretative Approach. The Academy of 
Management Journal, 43(1), 9-25.

Šímová, Z. (2010). To Work or not to work: Motivation to work after reaching retirement age. In European Centre for the Development of Vocational Training (Cedefop) (Ed.), Working and ageing: Emerging theories and empirical perspectives. Luxembourg: Publications Office of the European Union.

Strauss, A. L., \& Corbin, J. M. (1997). Grounded theory in practice. Thousand Oaks: Sage Publications.

Thody, A. (2011). Emeritus professors of an English university: how is the wisdom of the aged used? Studies in Higher Education, 36(6), 637. http://dx.doi.org/10.1080/03075079.2010.488721

Yeandle, S. (2005). Older workers and work-life balance. York: Joseph Rowntree Foundation, Sheffield Hallam University.

\section{Notes}

Note 1 . Table 1 is a summary of the sample and the number given to each respondent is attached to the illustrative quotes

Note 2. These are the numbers involved in activities

\section{Appendix 1}

\section{OLDER ACADEMICS QUESTIONNAIRE}

This open ended questionnaire has been designed to investigate the reasons why older academics continue to be involved in academic activities after usual retirement age. If you come into that category, please fill in the following questionnaire.

\begin{tabular}{ll}
\hline Name (optional) & Age over 65 (optional) \\
Country & University/Affiliation \\
Area of expertise & Normal age of retirement in your country/institution \\
\hline
\end{tabular}

\section{Please write as much as you want. Feel free to increase the spaces and consider the following as prompts.}

What are your main reasons for continuing to be involved in academic activities?

Please describe what those activities currently involve.

What are your areas of expertise?

Please describe the ideal range of academic and other activities you would like to have in retirement.

What aspects of your work do you need to keep up with so as to stay engaged?

Please describe any barriers you have found for your continuing engagement in academic life.

What types of support for your continuing academic activities do you need and to what extent you have access to them?

Are there aspects of current institutional or governmental policies in your country that would need to be changed to ensure continued support for the involvement of older academics?

Anything else you want to add? 